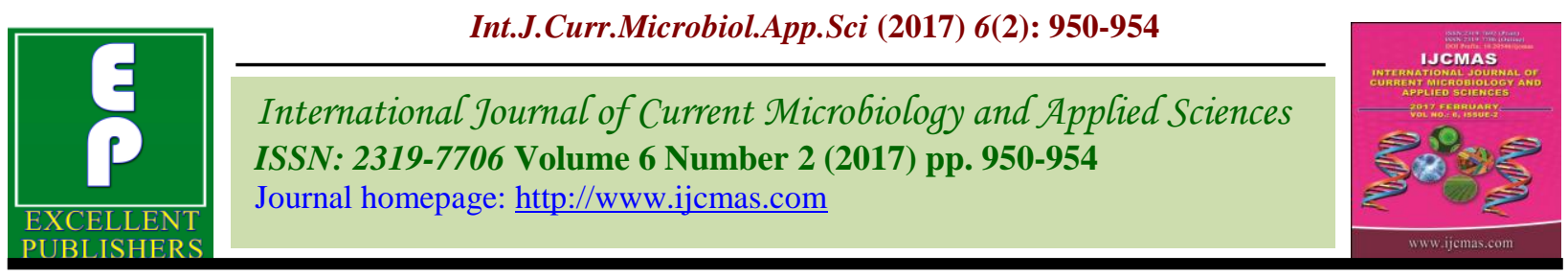

Original Research Article

http://dx.doi.org/10.20546/ijcmas.2017.602.106

\title{
Effect of Temperature and Salinity on the Growth of Sclerotinia sclerotiorum Causing Head Rot of Cabbage
}

\author{
K. Kamesh Krishnamoorthy*, A. Sankaralingam and S. Nakkeeran \\ Department of Plant Pathology, Centre for Plant Protection Studies, Tamil Nadu Agricultural \\ University, Coimbatore-641003, India \\ *Corresponding author
}

\begin{tabular}{|c|c|}
\hline & A B S T R A C T \\
\hline Keywords & \multirow{4}{*}{$\begin{array}{l}\text { Sclerotinia sclerotiorum is a temperate plant pathogen. It is soil borne and has a } \\
\text { worldwide distribution. It affects cabbage leading to a diseased condition called head } \\
\text { rot in which rotting of fully grown cabbage heads takes place. The rotted cabbage } \\
\text { heads exhibit cottony white mycelial growth on their surface. With advancement of } \\
\text { the disease the mycelial growth becomes dense and numerous carbon black coloured } \\
\text { bodies called sclerotia are formed on the surface. Effect of temperature and salinity } \\
\text { was studied to determine the optimum temperature for growth of the pathogen and the } \\
\text { optimum salinity of soil tolerable for the pathogen growth respectively. Results } \\
\text { indicated that temperature of } 20^{\circ} \mathrm{C} \text { was the most optimum for the pathogen growth and } \\
\text { formation of sclerotia. Growth of } S \text {. sclerotiorum was maximum at } 1 \text { per cent NaCl } \\
\text { concentration. The growth of the pathogen decreased with increasing salinity levels. } \\
\text { Thus the study demonstrated the optimum temperature and salinity for the pathogen } \\
\text { growth. }\end{array}$} \\
\hline $\begin{array}{l}\text { Sclerotinia } \\
\text { sclerotiorum, } \\
\text { sclerotia, cabbage, } \\
\text { temperature, } \\
\text { salinity. }\end{array}$ & \\
\hline Article Info & \\
\hline $\begin{array}{l}\text { Accepted: } \\
\text { 20 January } 2017 \\
\text { Available Online: } \\
\text { 10 February } 2017\end{array}$ & \\
\hline
\end{tabular}

\section{Introduction}

Sclerotinia sclerotiorum is a vigorous plant pathogen and affects temperate crops around the world (Bolton et al., 2006). It infects cabbage leading to a diseased condition known as head rot. The disease leads to watery rot of fully grown cabbage heads in the field, during post harvest operations and storage (Hudyncia et al., 2000). This pathogen is recognized as important due to its worldwide distribution (Adams and Ayers, 1979; Purdy, 1979), its wide host range (Schwartz et al., 1977; Purdy, 1979; Boland and Hall, 1994) and the difficulties encountered in controlling the diseases it causes (Lumsden, 1979; Steadman, 1979). Sclerotia are the primary survival structures of the pathogen (Korf and Dumont, 1972). Sclerotia formed on or within the host tissue are dislodged on the soil surface by wind or during harvesting and threshing which are distributed in the vertical soil profile during land preparation (Cook et al., 1975). Approximately 90 per cent of the life cycle of Sclerotinia species is spent in soil as sclerotia (Adams and Ayers, 1979). Sclerotia are hard asexual resting structures composed of vegetative hyphal cells which become interwoven and aggregate together. There is a huge variation in the morphology of sclerotia when it is produced on different substrates (Kamesh et al., 2016). S.sclerotiorum attacks nearly all kinds of succulent plants including 
flowers, shrubs, weeds and almost all vegetables (Chupp and Sherf, 1960). The pathogen has a broad host range which includes high value crops like alfalfa, bean, cabbage, canola, lettuce, peanut, soybean, sugarbeet, sunflower, tobacco and tomato (Farr et al., 1989). Seed infection by this pathogen has been reported in dry beans (Blodgett et al., 1946; Hungerford et al., 1953; Steadman et al., 1975), soybean (Nicholson et al., 1972; Stovold and Priest, 1986; Hartman et al., 1998; Hoffman et al., 1998) and sunflower (Sackston et al., 1960).

In India head rot of cabbage was first reported during Febraury 1978 from Kodaikanal area in Dindigul district of Tamil Nadu (Alagianagalingam et al., 1978). Infection of cabbage can occur when infected materials such as neighbouring cabbage plants, fallen flower petals, or pollen contact with healthy tissue (Mc Lean, 1949; Mc Lean 1958; Dillard et al., 1986). Long distance transmission potential of Sclerotinia spp. is most likely by seed infected with mycelia, or sclerotia mixed with the seed (Blodgett et al., 1946; Adams and Ayers, 1979).

Kapoor (1994) multiplied S.sclerotiorum at $24 \pm 1^{\circ} \mathrm{C}$ on PDA medium. Nguyen and Dohroo (2006) reported that the optimum temperature range for the growth of the pathogen lied between 20 and $25^{\circ} \mathrm{C}$. Optimum temperature for production of sclerotia was $15-20^{0} \mathrm{C}$. Growth of the pathogen was found to be poor at $30^{\circ} \mathrm{C}$. Monika et al., (2013) found $25-30^{\circ} \mathrm{C}$ as optimum temperature for growth of $S$. sclerotiorum in liquid media.

Syed and Saleem (2004) observed growth of S. sclerotiorum after 7 days in media amended with 1 per cent $\mathrm{NaCl}$ which progressed slowly and filled the plate after 15 days. Rapid growth of S. sclerotiorum was observed on unamended medium with a growth rate of $25.7 \mathrm{mmd}^{-1}$. Growth rate decreased with decreasing solute potential. Maximum production of sclerotia was observed on medium amended with 2 per cent $\mathrm{NaCl}$ (Mansour et al., 2008).

\section{Materials and Methods}

\section{Isolation of pathogen}

Cabbage plants showing symptoms of Sclerotinia head rot were collected from Kothagiri area in Nilgiris district of Tamil $\mathrm{Nadu}$. The age of the crop varied from 60 to 75 days. Sclerotia collected from infected cabbage heads were surface sterilized with 0.1 per cent mercuric chloride and rinsed with three changes of sterile water. The surface sterilized sclerotia were plated on PDA in sterile Petri plates and kept in an incubator at $19^{0} \mathrm{C}$ for 5 days. The fungus was subcultured and maintained on Potato Dextrose agar (PDA). The stock cultures were maintained in PDA slants for long time storage under refrigerated condition at $4^{\circ} \mathrm{C}$.

\section{Effect of temperature on growth of $S$. sclerotiorum}

Petri plates containing uniform quantities of sterilized PDA medium were inoculated with 5 day old mycelial discs of the pathogen and incubated at different temperatures viz., 10, $15,20,25,30,35$ and $40^{\circ} \mathrm{C}$. Each treatment was replicated four times and data were recorded on radial growth of mycelium and number of sclerotia formed per plate.

\section{Effect of salinity on the growth of $S$.} sclerotiorum

Petri plates containing uniform quantity of sterilized PDA medium were amended with $\mathrm{NaCl}$ at different concentrations viz., $0,1,2,3,4,5,6,7,8,9$ and $10 \%$. The plates were inoculated with 5-day-old mycelial disks of pathogen. Each treatment was replicated 
three times and data were recorded on radial growth of mycelium and number of sclerotia formed per plate.

\section{Statistical analysis}

The data recorded were analysed statistically using the IRRISTAT version 92 developed by the International Rice Research Institute (IRRI), the Philippines (Gomez and Gomez, 1984).Prior to statistical analysis of variance (ANOVA) the percentage values of the disease index were arcsine transformed. Data were subjected to analysis of variance (ANOVA) at two significant levels $(\mathrm{P}<0.05$ and $\mathrm{P}<0.01)$ and means were separated by Duncan's Multiple Range Test (DMRT).

\section{Results and Discussion}

Effect of temperature on the growth of $S$. sclerotiorum

The effect of temperature on the growth of $S$. sclerotiorum was observed on 3 and 5 DAI (Table 1). Maximum mycelial growth was observed when the pathogen was incubated at temperature of $20^{\circ} \mathrm{C}(60.25 \mathrm{~mm}$ and 88.75 $\mathrm{mm})$ followed by temperature of $15^{\circ} \mathrm{C}(32.5$ $\mathrm{mm}$ and $74.50 \mathrm{~mm}$ ). Least growth was observed at temperature of $30^{\circ} \mathrm{C}(3.75 \mathrm{~mm}$ and $7.25 \mathrm{~mm}$ ). Growth of the pathogen was absent at temperature of $35^{\circ} \mathrm{C}$. Sclerotial production was maximum at temperature of $20^{\circ} \mathrm{C}(15.5)$ and least at $15^{\circ} \mathrm{C}(7.25)$. There was no production of sclerotia at $10^{\circ} \mathrm{C}$ and beyond $30^{\circ} \mathrm{C}$.

\section{Effect of salinity on the growth of $S$. sclerotiorum}

The mycelial growth of pathogen was highest in medium unamended with $\mathrm{NaCl}$ at 3DAI and 5DAI (50.0 $\mathrm{mm}$ and $89.0 \mathrm{~mm}$ ) (Table 2). Growth rate decreased with increasing concentration of $\mathrm{NaCl}$. $\mathrm{NaCl}$ concentration of 1 per cent favoured highest mycelial growth (38.7 $\mathrm{mm}$ and $76.3 \mathrm{~mm}$ ) followed by 2 per cent $\mathrm{NaCl}$ concentration $(33.3 \mathrm{~mm}$ and 61.3 $\mathrm{mm})$ at 3 and 5 DAI. There was no growth of pathogen at and 10 per cent $\mathrm{NaCl}$ concentration at both the time intervals. Unamended medium produced highest number of sclerotia (18.3) followed by medium with 3 per cent $\mathrm{NaCl}(18)$.

Table.1 Effect of different temperature on growth of S. sclerotiorum under in vitro

\begin{tabular}{|c|c|c|c|c|}
\hline \multirow{2}{*}{$\begin{array}{c}\text { Sl. } \\
\text { No. }\end{array}$} & $\begin{array}{c}\text { Temperature } \\
\left.\mathbf{(}^{\mathbf{0}} \mathbf{C}\right)\end{array}$ & \multicolumn{2}{|c|}{ Mycelial growth } & $\begin{array}{c}\text { No. of } \\
\text { Sclerotia } \\
\text { produced /plate }\end{array}$ \\
\cline { 3 - 4 } & 10 & $3.25^{\mathrm{c}}(1.90)$ & $\left.11.75^{\mathrm{c}} 3.48\right)$ & $0.0^{\mathrm{c}}(0.70)$ \\
\hline 1 & 15 & $32.5^{\mathrm{b}}(5.72)$ & $74.50^{\mathrm{b}}(8.65)$ & $7.25^{\mathrm{b}}(2.77)$ \\
\hline 3 & 20 & $60.25^{\mathrm{a}}(7.78)$ & $88.75^{\mathrm{a}}(9.44)$ & $15.5^{\mathrm{a}}(3.98)$ \\
\hline 4 & 25 & $29.00^{\mathrm{b}}(5.42)$ & $74.00^{\mathrm{b}}(8.63)$ & $7.75^{\mathrm{b}}(2.86)$ \\
\hline 5 & 30 & $3.75^{\mathrm{c}}(2.03)$ & $7.25^{\mathrm{d}}(2.77)$ & $0.0^{\mathrm{c}}(0.70)$ \\
\hline 6 & 35 & $0.0^{\mathrm{d}}(0.70)$ & $0.0^{\mathrm{e}}(0.70)$ & $0.0^{\mathrm{c}}(0.70)$ \\
\hline
\end{tabular}

*Days after inoculation

Figures in parantheses are square root transformed values

In a column means followed by the same letter are not significantly different at the 5\% level of DMRT 
Table.2 Effect of salinity on the growth of S. sclerotiorum under in vitro

\begin{tabular}{|c|c|c|c|c|}
\hline \multirow[b]{2}{*}{ Sl. No. } & \multirow{2}{*}{$\begin{array}{c}\mathrm{NaCl} \text { concentration } \\
(\%)\end{array}$} & \multicolumn{2}{|c|}{ Mycelial growth } & \multirow[b]{2}{*}{ No. of sclerotia/plate } \\
\hline & & $\begin{array}{c}\text { 3DAI* } \\
\text { (mm) }\end{array}$ & $\begin{array}{l}\text { 5DAI } \\
(\mathrm{mm})\end{array}$ & \\
\hline 1 & 1 & $\begin{array}{l}38.7^{b} \\
(6.2)\end{array}$ & $\begin{array}{l}76.3^{b} \\
(8.76)\end{array}$ & $\begin{array}{c}17.0^{\mathrm{a}} \\
(4.17)\end{array}$ \\
\hline 2 & 2 & $\begin{array}{l}33.3^{\mathrm{b}} \\
(5.8)\end{array}$ & $\begin{array}{c}61.3^{\mathrm{c}} \\
(7.86)\end{array}$ & $\begin{array}{l}16.0^{\mathrm{a}} \\
(4.05)\end{array}$ \\
\hline 3 & 3 & $\begin{array}{l}20.0^{c} \\
(4.5)\end{array}$ & $\begin{array}{l}52.6^{\mathrm{d}} \\
(7.28)\end{array}$ & $\begin{array}{l}18.0^{\mathrm{a}} \\
(4.29)\end{array}$ \\
\hline 4 & 4 & $\begin{array}{l}18.7^{\mathrm{c}} \\
(4.3)\end{array}$ & $\begin{array}{l}51.6^{\mathrm{de}} \\
(7.21)\end{array}$ & $\begin{array}{c}7.0^{\mathrm{b}} \\
(2.75)\end{array}$ \\
\hline 5 & 5 & $\begin{array}{l}13.0^{d} \\
(3.6)\end{array}$ & $\begin{array}{l}46.6^{\mathrm{de}} \\
(6.85)\end{array}$ & $\begin{array}{l}8.0^{\mathrm{b}} \\
(2.90)\end{array}$ \\
\hline 6 & 6 & $\begin{array}{l}11.7^{\mathrm{d}} \\
(3.4)\end{array}$ & $\begin{array}{c}44.6^{\mathrm{e}} \\
(44.52)\end{array}$ & $\begin{array}{c}7.3^{\mathrm{b}} \\
(2.79)\end{array}$ \\
\hline 7 & 7 & $\begin{array}{l}4.0^{\mathrm{e}} \\
(2.0)\end{array}$ & $\begin{array}{c}25.2^{f} \\
(25.33)\end{array}$ & $\begin{array}{c}6.0^{\mathrm{b}} \\
(2.52)\end{array}$ \\
\hline 8 & 8 & $\begin{array}{l}2.7^{\mathrm{e}} \\
(1.7)\end{array}$ & $\begin{array}{c}22.0^{f} \\
(4.74)\end{array}$ & $\begin{array}{c}3.0^{\mathrm{c}} \\
(1.85)\end{array}$ \\
\hline 9 & 9 & $\begin{array}{l}0.0^{f} \\
(0.7)\end{array}$ & $\begin{array}{c}0.0^{\mathrm{g}} \\
(0.70)\end{array}$ & $\begin{array}{c}0.0^{\mathrm{d}} \\
(0.70)\end{array}$ \\
\hline 10 & 10 & $\begin{array}{l}0.0^{f} \\
(0.7)\end{array}$ & $\begin{array}{c}0.0^{\mathrm{g}} \\
(0.70)\end{array}$ & $\begin{array}{c}0.0^{\mathrm{d}} \\
(0.70)\end{array}$ \\
\hline 11 & Control & $\begin{array}{l}50.0^{\mathrm{a}} \\
(7.0)\end{array}$ & $\begin{array}{c}89.0^{\mathrm{a}} \\
(9.46)\end{array}$ & $\begin{array}{l}18.3^{\mathrm{a}} \\
(4.32)\end{array}$ \\
\hline
\end{tabular}

*Days after inoculation

Figures in parantheses are square root transformed values

In a column means followed by the same letter are not significantly different at the $5 \%$ level of DMRT

In the current study, maximum mycelial growth and sclerotial production by S. sclerotiorum was observed at temperature of $20^{\circ} \mathrm{C}$ followed by $15^{\circ} \mathrm{C}$. Least growth of the pathogen was observed at temperature of $30^{\circ} \mathrm{C}$. Coe (1944) reported best growth of the pathogen at temperature range of 19 to $20^{\circ} \mathrm{C}$ on PDA medium. Abawi and Grogan (1975) reported temperature of $20-25^{\circ} \mathrm{C}$ as optimum for growth and sclerotial production

S. sclerotiorum. Mycelial plugs of S. sclerotiorum inoculated on PDA had the highest growth rate at $25^{\circ} \mathrm{C}$. No growth was observed at 35,40 and $45^{\circ} \mathrm{C}$ (Mansour et al., 2008). The results of effect of salinity levels on the pathogen growth showed that mycelial growth of $S$. sclerotiorum was highest in medium unamended with $\mathrm{NaCl}$ and growth rate decreased with increasing concentration of $\mathrm{NaCl} . \mathrm{NaCl}$ concentration of 1 per cent favoured highest growth. El-Abyad et al. (1992) reported that myceliogenic germination of sclerotia of S. sclerotiorum decreased when it was grown on Czapek's Dox agar medium amended with salts. Production of sclerotia following myceliogenic germination is decreased by over 50 per cent with increasing salt concentration.

\section{References}

Abawi, G.S. and Grogan, R.G. 1975. Source of primary inoculum and effects of temperature and moisture on infection of beans by Whetzelinia sclerotiorum. Phytopathol., 65: 300-309.

Adams, P.B. and Ayers, W.A. 1979. Ecology of 
Sclerotinia species. Phytopathol., 69: 896899.

Blodgett, E. C. 1946. The Sclerotinia rot disease of beans in Idaho. Plant Dis. Rep., 30:137139.

Boland, G.J. and Hall, R. 1994. Index of plant hosts of Sclerotinia sclerotiorum. Can. J. Plant Pathol., 16: 93-108.

Bolton, M.D., B.P.H.J., Thomma, B.D. and Nelson. 2006. Sclerotinia sclerotiorum (Lib.) de Bary: Biology and molecular traits of a cosmopolitan pathogen, Mol. Plant Pathol., 7: 1-16.

Chupp, C. and Sherf, A.F. 1960. Sclerotinia diseases in Vegetable Diseases and their Control. The Ronald Press Company, New York, pp: 43-46.

Coe D.M. 1944. Variations in single ascospore isolates of Sclerotinia sclerotiorum. Mycologia, 36: 235-241.

Coe D.M. 1944. Variations in single ascospore isolates of Sclerotinia sclerotiorum. Mycologia, 36: 235-241.

El-Abyad, M.S., Hindorf, H. and Rizk, M.A. 1992. Impact of salinity stress on soil-borne fungi of sugarbeet. Plant and Soil, 110: 3337.

Farr, D.F., Bills, G.F., Chamuris, G.P. and Rossman, A.Y. 1989. Fungi on Plants and Plant Products in the United States. In:The American Phytopathol. Soc., p.1252.

Hudyncia, J., Shew, H.D., Cody, B.R. and Cubeta, M.A. 2000. Evaluation of wounds as a factor to infection of cabbage by ascospores of Sclerotinia sclerotiorum. Plant Dis., 84(3): 316-320.

Kamesh, K.K., and Sankaralingam, A. 2016. Morphological variations of sclerotia of Sclerotinia sclerotiorum produced on different substrates. Trends in Biosci., 9(5): 364-366.
Kapoor, K.S. 1994. Stipe regeneration potential of sclerotia of Sclerotinia sclerotiorum (Lib.) de Bary. Pl. Dis. Res., 9(1): 98-100.

Korf, R.P. and Dumont, K.P. 1972. Whetzelinia, a new generic name for Sclerotinia sclerotiorum and S. tuberosa. Mycologia, 64: 248-251.

Lumsden, R.D. 1979. Histology and physiology of pathogenesis in plant diseases caused by Sclerotinia species. Phytopathol., 69: 890895.

Mansour, T.A., Nida, Y.A. and Patrice, S. 2008. Effect of salinity, temperature and carbon source on the growth and development of sclerotia of Sclerotinia sclerotiorum isolated from semi-arid environment. Pl. Pathol. J., 24(4): 407-416.

Monika, S., Sharma, O.P., Someshwar, B. and Neetu, P. 2013. Effect of systemic fungicides, culture media, temperature and $\mathrm{pH}$ on growth of Sclerotinia sclerotiorum causing white mold of chickpea. Ann. Pl. Protec. Sci., 21(1): 136-139.

Nguyen, D.C. and Dohroo, N.P. 2006. Morphological, cultural and physiological studies on Sclerotinia sclerotiorum causing stalk rot of cauliflower. Omonrice, 14: 71-77.

Purdy, L.H. 1979. Sclerotinia sclerotiorum: History, diseases and symptomatology, host range, geographic distribution and impact. Phytopathol., 69: 875-880.

Schwartz, H.F. and Steadman, J.R. 1977. Factors affecting sclerotium populations and apothecium production by Sclerotinia sclerotiorum. Phytopathol., 68: 383-388.

Steadman, J.R. 1979. Control of plant diseases caused by Sclerotinia species. Phytopathol., 69: 904-907.

Syed, A.H. and Saleem, S. 2004. Effect of sea salt on in vitro growth of Sclerotinia sclerotirum. Pak. J. Bot., 36(3):677-682.

\section{How to cite this article:}

Kamesh Krishnamoorthy, K., A. Sankaralingam and Nakkeeran, S. 2017. Effect of Temperature and Salinity on the Growth of Sclerotinia sclerotiorum Causing Head Rot of Cabbage. Int.J.Curr.Microbiol.App.Sci. 6(2): 950-954. doi: http://dx.doi.org/10.20546/ijcmas.2017.602.106 